
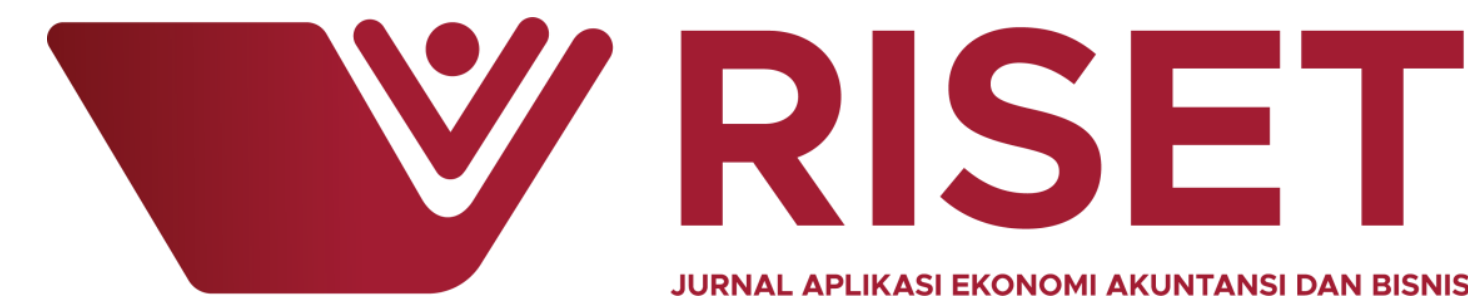

JURNAL APLIKASI EKONOMI AKUNTANSI DAN BISNIS

\title{
THE EFFECT OF WORD OF MOUTH ON BRAND IMAGE OF A POPULAR INDONESIAN DONUT BRAND
}

\author{
Alex Winarno ${ }^{1)}$, Mahir Pradana ${ }^{2)}$, Mahendra Fakhri ${ }^{3)}$, Haeruddin Hafid ${ }^{4)}$, Ambar Kania \\ Rahimiah $^{5)}$, \\ 1,2,3,5) Telkom University, Indonesia, ${ }^{4)}$ STIE Muhammadiyah Mamuju
}

\section{INFO ARTIKEL}

The Effect Of Word Of Mouth On Brand Image Of A Popular Indonesian Donut Brand

Submitted:

11 - April - 2019

Revised:

21 - Agustus - 2019

Accepted:

24 - Agustus - 2019

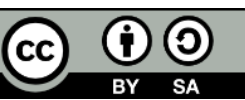

\begin{abstract}
A Brand must innovate to create a positive impression of consumers. When a consumer feels happy and satisfied with a product, the emotional impact will encourage loyalty, and positive word of mouth will increase. The purpose of this research is to know how big influence of word of mouth to brand image of J.CO Donuts \& Coffee. The independent variable (X) in this research is word of mouth, and the dependent variable $(\mathrm{Y})$ is a brand image. This research uses a quantitative method with a descriptive and causal research type. This research was conducted on 75 respondents and used simple linear regression analysis and data processing using SPSS version 21. Based on the results of hypothesis testing, word of mouth has an influence on brand image J.CO. The results of determination coefficient word of mouth influence to brand image by $46,7 \%$.
\end{abstract}

Keywords: brand image, word of mouth, marketing, business administration

E-mail:alexwinarno@telkomuniversity.ac.id,mahirpradana@gmail.com,mahendrafakhri@telkomuniversity.ac.id, haeruddinhafid19@yahoo.co.id,ambar.rahimiah@yahoo.co.id

\section{INTRODUCTION}

The culinary business is a food business that is really popular and always evolve in every period of time (Madiawati \& Pradana, 2016). In the world of marketing, communication plays an important role in increasing sales of a company's products or services (Nur Fadillah Ab, Bazlan, Ghazali, \& Rasam, 2014) From the consumer side, communication is very helpful to get information about the company and its products to be right in making purchasing decisions(Natyari \& Pradana, 2016). 
Promotional media that one of them has the most important and effective role in marketing is word of mouth communication (Maharani, Pradana, \& Wijaksana, 2016). Word of mouth (WOM) is one form of positive information related to one product, so consumers are more confident in personal word of mouth when compared to advertisements of some products and services (Wijaksana, Indra, \& Pradana, 2018). Every company must continue to maintain product quality and motivated to create a positive impression from consumers so that they are loyal and bring new customers through word of mouth. Brand image (brand image) is the perception and beliefs of the consumer, as reflected in the long-term memory of the name of a strong corporate brand (Bendouda, Rachedi, \& Haffaf, 2018).

If WOM marketing is capable of generating a sense of satisfaction to the customer, and not easily mistaken by a competitor's message, the infectious WOM succeeds in making the company's brand and image superior in the market (Widodo, Rubiyanti, \& Nandary, 2015). Therefore, the factors that support the brand image need to be enhanced by each company in order to give the impression and positive memory for consumers, such as satisfactory service, attractive marketing, quality products, and others (Maharani et al., 2016).

One of the companies that implement marketing strategies using word of mouth as a media campaign that is company J.CO Donuts \& Coffee. Based on the results of the above description of the author interested to know how the influence of word of mouth on the brand image at the company J.CO Donuts \& Coffee. This research aims to know and analyze whether word of mouth of J.CO product is effective in increasing brand image.

\section{LITERATURE REVIEW}

Most processes of communication between humans are done by communicating with other people. Communication is carried out in a manner mouth to mouth with other people because every the day someone spoke, exchanged ideas, exchanged information, giving each other opinions (Nur Fadillah Ab et al., 2014). Process of communication is the nature of humans who wants to socialize with other people. Word of mouth communication or mouth communication to mouth depends on the dissemination of the information someone does to someone else. According to (Brown, Barry, Dacin, \& Gunst, 2005) word of mouth occurs when consumers talk to other people regarding his opinion about a brand, certain products, services or companies on other people. Consumers pay more attention to information that comes from people who are trusted, like friends, relatives, or family. Sayings or words from mouth to mouth (word of mouth) can be a method that is effective in promotion. In general, word of mouth (WOM) delivered 'from consumers,' 'by consumers' and 'for consumers,' so satisfied consumers or customers can become advertising media for companies (Rehman, Waqas, Abid, Ehsan, \& Lodhi, 2018).

According to (Hasan, 2010), word of mouth is the act of giving consumers information to other consumers from someone to other (non-personal) non-commercial, brand, product, or service. WOM is very effective to influence a person because the information provided by another individual is usually considered honest. Consumers are more likely to trust the product information they get from their acquaintances than with information posted in the media. Still, according to (Hasan, 2010), there are four words of mouth indicators, namely mutual dialogue, pass-along effect, knowledge diffusion, and cause and effect. (Kotler \& Keller, 2009) Believe that brand image is an impression 
that there is in the minds of consumers about a brand formed by the message and consumer experience of the brand, thus creating an image that is in the minds of consumers. Meanwhile, according to (Rahman, 2010), brand image is the image of a brand whose purpose is to create a trend for consumers of the brand.

(Sisilia, Peranginangin, Setyorini, \& Moeliono, 2015) Argues that brand image component consists of three parts, namely corporate image (image), user image (image), and product image (product image). According to (Saputra \& Dewi, 2016), if the customer is happy, the emotional impact will encourage loyalty and positive word of mouth increases. Every touch of customer or customer experience has the potential to increase or decrease the strength and value of the brand image.
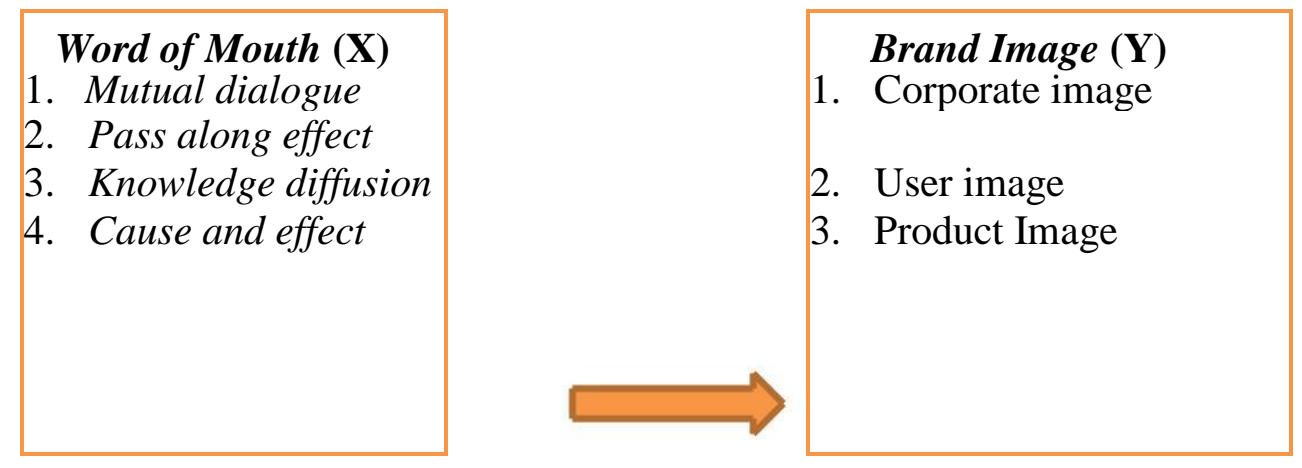

\section{Figure 1: \\ Research \\ Framework}

Hypothesis in this research is whether word of mouth has no significant effect on brand image of J.CO Donuts \& Coffee among consumers, or whether word of mouth significantly influences the brand image of J.CO Donuts \& Coffee.

\section{DISCUSSION}

This research is descriptive and causal research. The research method used in this research is quantitative method with data analysis technique using simple linear regression. Population in this research is a student of Business Administration year 2013 of Telkom University. The sampling technique used is the probability sampling method of simple random sampling, with the number of respondents taken as many as 75 students. The type of data needed for this research is primary data and secondary data. This study is an experiment which also uses quantitative extermination ties with the data processing uses the regression analysis (Natyari \& Pradana, 2016).

The sample used in this research is 75 respondents, all of whom come from students and Business Administration students who enrolled in Telkom University. Based on the identity of the respondents are $45 \%$ male sex and 55\% female gender aged 21-23 years, and as much as $48 \%$ income Rp 1,000.001-Rp 2,000,000 per month. The majority of respondents as much as 53\% of people consume J.CO as much as 1 time in a month. And of the 75 respondents, as many as $83 \%$ of people reasoned to consume J.CO because like and want.

The result of the validity test shows that 15 statements from 15 research statements are valid, with Corrected item-total Correlation more than 0.361 (r-table). While the reliability test results show the value of Cronbach's Alpha count more than 0.600, so the 
instrument can be used to measure research variables, because it has qualified reliability.

\section{Descriptive Analysis}

Based on the results of research and the results of descriptive analysis of variable word of mouth (X) on J.CO Donuts \& Coffee obtained an average total score of $75.05 \%$ which overall entered in the category "Good" on the continuum line or can be said that word of mouth about J.CO among respondents has been good as what they feel and natural. This result shows that the four dimensions of word of mouth really happened and done well by the respondents of the research, which are Business Administration students of Telkom University. A

As a tool or media promotion company, J.CO brand also plays an image in sharing the good or bad experience of J.CO products. It also shares knowledge about J.CO product quality, which makes the respondents recommend J.CO product and J.CO outlet as a good hangout place compared to other similar competitors.

Description of Brand Image J.CO according to the samples based on the results of research and the results of descriptive analysis of brand image variables (Y) on J.CO Donuts \& Coffee got the average total score of $78.21 \%$ the score is in the category of "Good" on the continuum line or can be said that J.CO brand image according to the respondents was good. J.CO brand has been seen as a decent brand in the mindset of the majority of respondents who are consumers of J.CO, seen from the results of descriptive analysis included in the category of "Good" which shows that it is a product popular among consumers. The J.CO brand represents the modern style in the minds of consumers, and the J.CO brand as a whole has a satisfactory product quality.

\section{Classic assumption test: Normality Test}

To further ensure that the data is normally distributed or not, it is necessary to test the Kolmogorov-Smirnov One-Sample Test. Here is a normality test based on KolmogorovSmirnov non-parametric statistical test $(\mathrm{K}-\mathrm{S})$. Test results can be seen in the table below:

Table 1

One-Sample Kolmogorov-Smirnov Test

\begin{tabular}{|c|c|c|}
\hline & & $\begin{array}{l}\text { Unstandardized } \\
\text { Residual }\end{array}$ \\
\hline \multicolumn{2}{|l|}{$\mathrm{N}$} & 75 \\
\hline \multirow{3}{*}{ Normal Parameters, } & $\begin{array}{l}\text { Mean } \\
\text { Std }\end{array}$ & .0000000 \\
\hline & Deviation & .45469949 \\
\hline & Absolute & .069 \\
\hline \multirow{2}{*}{\multicolumn{2}{|c|}{$\begin{array}{r}\text { Most Extreme Differences Positive } \\
\text { Negative }\end{array}$}} & .069 \\
\hline & & -.052 \\
\hline \multicolumn{2}{|l|}{$\begin{array}{l}\text { Kolmogorov-Smirnov } \\
\text { Z }\end{array}$} & .597 \\
\hline \multicolumn{2}{|l|}{ Asymp. Sig. (2-tailed) } & .868 \\
\hline
\end{tabular}

a. Test distribution is Normal.

b. Calculated from data. 
Table 1 shows that the value of Asymp. Sig. ( 2 tailed) is 0.868 and above the significant value $(0.05)$, in other words the overall data is normally distributed.

\section{Heteroscedasticity Test}

Heteroskedasticity test was done with a plot graph between the predictor value of a free variable that is ZPRED with residual SRESID with the assistance of SPSS software. A good regression model is not affected by heteroscedasticity (Madiawati \& Pradana, 2016). It is proved by the spreading points on the scatter diagram and does not form a distinct, clear pattern, as in Figure 2 below:

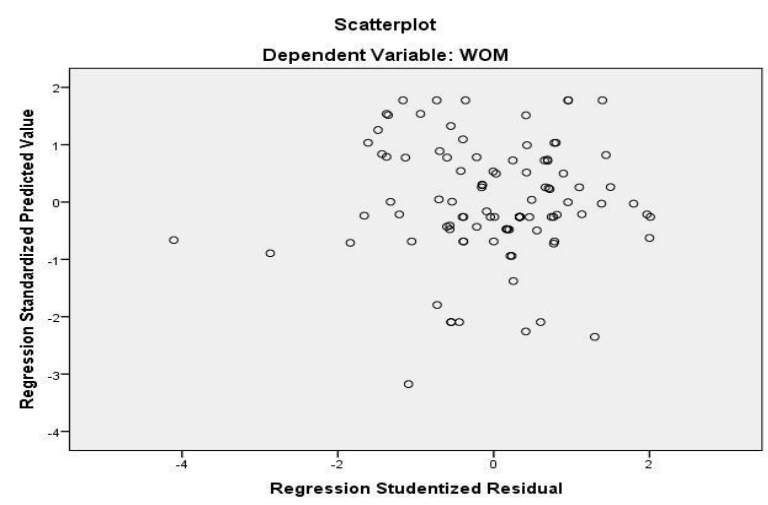

Figure 1: Heterokedasticity Scatterplot

Afterward, we see the coefficient of regression analysis:

Table 2

Coefficients

\begin{tabular}{|c|c|c|c|c|c|}
\hline \multirow[t]{2}{*}{ Model } & \multicolumn{2}{|c|}{$\begin{array}{r}\text { Unstandardized } \\
\text { Coefficients }\end{array}$} & \multirow{2}{*}{$\begin{array}{l}\text { Standardized } \\
\text { Coefficients } \\
\text { Beta }\end{array}$} & \multirow[t]{2}{*}{$\mathrm{t}$} & \multirow[t]{2}{*}{ Sig. } \\
\hline & $\mathrm{B}$ & Std. Error & & & \\
\hline (Constant) & 1.127 & .286 & & $\begin{array}{l}3.94 \\
5\end{array}$ & .000 \\
\hline WOM & .713 & .089 & .684 & $\begin{array}{l}8.00 \\
6\end{array}$ & .000 \\
\hline
\end{tabular}

a. Dependent Variable: BRAND_IMAGE

Based on the results of data processing in Table 2, a simple linear regression equation model can be formulated as follows:

$$
\begin{gathered}
\mathrm{Y}=\mathrm{a}+\mathrm{bX} \\
\text { Brand Image }=1,127+0,713 \mathrm{X}
\end{gathered}
$$




\section{Hypothesis Testing}

Hypothesis testing in this study was conducted to determine the significance of the hypotheses that have been formulated. The hypothesis test used is a partial hypothesis test (t-test)

Table 3

\section{T-test result}

Coefficients $^{\mathrm{a}}$

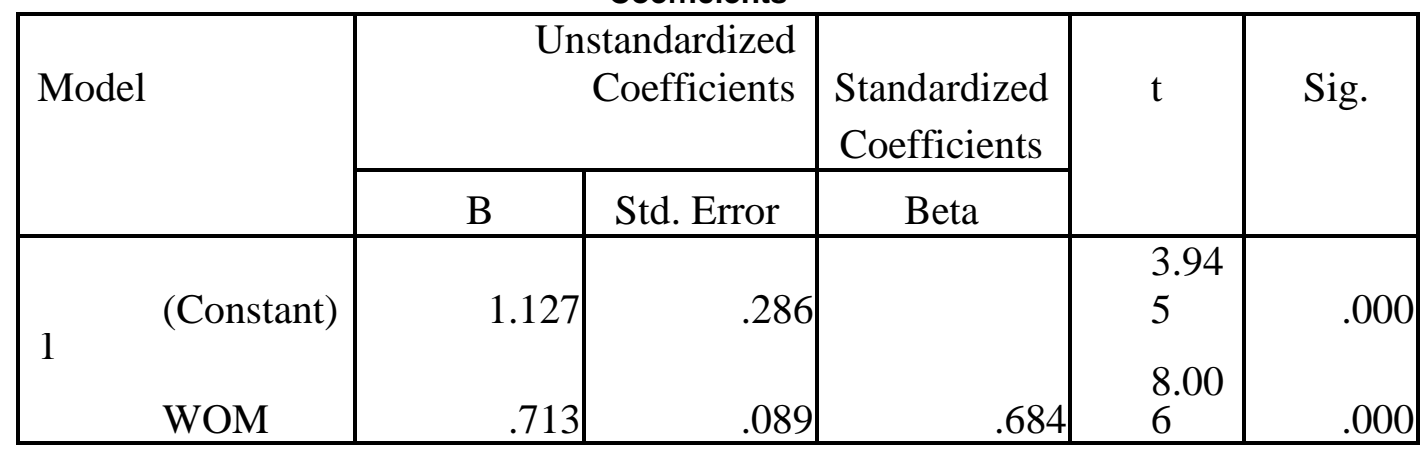

a. Dependent Variable: BRAND_IMAGE

Based on table 3 above, it is known that $t$ calculate $(8,006)>t$ table $(1,984)$ and with significance smaller than 0,005 , which is 0,000 . It means that Ho is rejected and $\mathrm{Ha}$ is accepted, then partially, there is a significant effect of the variable word of mouth (X) affecting the brand image $(\mathrm{Y})$ variable.

\section{Determinant Coefficient Test $\left(\boldsymbol{R}^{2}\right)$}

Based on the results of data processing, the determinant coefficient model can be formulated as follows:

\section{Table 4}

Determinant Coefficient Test Results

\begin{tabular}{|l|l|r|r|r|}
\hline Model & R & R Square & $\begin{array}{c}\text { Adjusted R } \\
\text { Square }\end{array}$ & $\begin{array}{c}\text { Std. Error of } \\
\text { the } \\
\text { Estimate }\end{array}$ \\
\hline 1 & $\begin{array}{c}.684 \\
\mathrm{a}\end{array}$ & .467 & .460 & .45780 \\
\hline
\end{tabular}

a. Predictors: (Constant), WOM

b. Dependent Variable: BRAND_IMAGE

The table shows that the value of $\mathrm{R}$ is 0,684 and $\mathrm{R}$ square $\left(\mathrm{R}^{2}\right)$ is 0,467 . This number is used to see the effect of word of mouth on a brand image simultaneously. The way to calculate $\mathrm{R}$ square uses the coefficient of determination (KD) using the formula as follows: 


$$
\begin{gathered}
\mathrm{KD}=\mathrm{r}^{2} \times 100 \% \\
=(0,684)^{2} \times 100 \%=46,7 \%
\end{gathered}
$$

This figure shows the coefficient of determination (KD) of $46.7 \%$. This shows that the influence of independent variables namely word of mouth (mutual dialogue, pass-along effects, knowledge diffusion, and cause and effect) on the dependent variable namely brand image (company image, user image, and product image) is $46.7 \%$ while the remaining $53.3 \%$ is influenced by other factors not examined in this study.

\section{CONCLUSION}

Based on the results of data analysis and discussion, then the conclusions that can be drawn from this research according to the research problem formulation are that word of mouth Business Administration student of 2013 Telkom University at J.CO Donuts \& Coffee is in the category of "Good" with a percentage of $75.05 \%$. The brand image of J.CO Donuts \& Coffee according to Business Administration student of 2013 Telkom University is in the "Good" category with a percentage value of $78.21 \%$. Based on the results of t-test and the coefficient of determination can be concluded that independent variables word of mouth significant effect on the dependent variable that is a brand image on J.CO Donuts \& Coffee of $46.7 \%$ while the remaining $53.3 \%$ influenced by other factors such as brand awareness, buying interest, and more.

The results of this study indicate that word of mouth variables affect the brand image of J.CO Donuts \& Coffee. Then J.CO company must continue to maintain good relationships with consumers so that consumers are always a media promotion of products and corporate brands to other consumers (Wijayangka, Sisilia, \& Ruhendi, 2017). The following are suggestions that the author can convey. Based on the calculation on the variable word of mouth $(\mathrm{X})$ obtained the lowest statement item that consumers have or do not like to share good or bad experiences that always remember J.CO with expressive" suggested J.CO Donuts \& Coffee should further enhance the factors that make the consumer happy when making a purchase that will be attached to the warning and emotional impacts such as likes, satisfaction, and joy, will encourage consumers to want to share good experiences about J.CO to others naturally. Factors that make consumers memorable can be started from close to the consumer, such as organizing the event "donut cooking class" for free with the community of customers J.CO. And provide attractive promotions such as "happy brunch" in order to provide breakfast and lunch that is food that is not too heavy but quite satisfying and practical for customers J.CO.

Based on the results of calculations on the variable image brand (Y) obtained the lowest statement item is "consumers feel when buying J.CO products while hangout at J.CO both in its outlets alone and with others, improve their social status." It was concluded that not all consumers of J.CO assumed that the hangout at J.CO outlets felt their social status increased. It is recommended that J.CO Donuts \& Coffee add value and touch the customer's emotional side when hanging out at the booth. It's like giving different nuances that make customers feel comfortable while sitting at the booth while enjoying a plate of donuts, a cup of coffee, and fresh yogurt with a fruit topping. This will enhance the image of J.CO brand, to create prestige and make hangout in J.CO as a modern lifestyle for its customers. This added value will make loyal customers willing to spend their money and time on J.CO. 
Alex Winarno ${ }^{1)}$, Mahir Pradana ${ }^{2)}$, Mahendra Fakhri ${ }^{3)}$, Haeruddin Hafid ${ }^{4)}$, Ambar Kania Rahimiah ${ }^{5)}$, The Effect Of Word Of Mouth ...

\section{REFERENCES}

Bendouda, D., Rachedi, A., \& Haffaf, H. (2018). Programmable architecture based on Software Defined Network for Internet of Things: Connected Dominated Sets approach. Future Generation Computer Systems.

Brown, T. J., Barry, T. E., Dacin, P. A., \& Gunst, R. F. (2005). Spreading the Word: Investigating Antecedents of Consumers' Positive Word-of-Mouth Intentions and Behaviors in a Retailing Context. Journal of the Academy of Marketing Science, 33(2), 123-138. Retrieved from http://link.springer.com/10.1177/0092070304268417

Hasan, A. (2010). Marketing Dari Mulut ke Mulut Word Of Mouth Marketing (Cetakan Pe.). Yogyakarta: Media Pressindo.

Kotler, P., \& Keller, K. L. (2009). Manajemen Pemasaran (edisi 13.). Jakarta: Penerbit Erlangga.

Madiawati, P. N., \& Pradana, M. (2016). Celebrity and halal certificates factors influence customers' buying interest. Actual Problems of Economics, (3), 109-116. Національна академія управління, вищий навчальний заклад.

Maharani, B., Pradana, M., \& Wijaksana, T. I. (2016). Instagram Electronic Word of Mouth's Effect Towards Purchasing Decision Arromanis Corner Store, Bandung, Indonesia. International Journal of Scientific Engineering and Applied Science (IJSEAS), 2(6).

Natyari, S. G., \& Pradana, M. (2016). Determinants Forming Uber Consumers ' Preferences in Bandung City, Indonesia. International Journal of Emerging Technologies in Engineering Research (IJETER), 10(6), 7.

Nur Fadillah Ab, A., Bazlan, M. J., Ghazali, R., \& Rasam, A. R. A. (2014).

Development of integrated Infectious Disease Information System (IDIS):

Geospatial-based components for Malaria Information System (GeoMIS). 2014 IEEE 5th Control and System Graduate Research Colloquium (Vol. 11, pp. 7579). IEEE. Retrieved from http://ieeexplore.ieee.org/document/6908699/

Rahman, A. (2010). Strategi Dahsyat Marketing Mix for Small Business: Cara Jitu Merontokan Pesaing. Jakarta Selatan: Trans Media Pustaka.

Rehman, Z., Waqas, M., Abid, M., Ehsan, U., \& Lodhi, S. (2018). Dynamics of Word of Mouth Marketing in Digital Era. International Journal of Global Sustainability, $3(1), \quad 1 . \quad$ Retrieved from http://www.macrothink.org/journal/index.php/ijgs/article/view/13950

Saputra, R., \& Dewi, C. K. (2016). The impact of brand trust on brand loyalty mediated by customer satisfaction: Case of Tokobagus.com (now OLX.co.id). Journal of Administrative and Business Studies, 1(1), 8-13.

Sisilia, K., Peranginangin, Y., Setyorini, R., \& Moeliono, N. (2015). A Framework of Affiliation Partnership between Univesity, SMEs, and Business Sector: A Case Study of PKBL Telkom, Indonesia. Procedia - Social and Behavioral Sciences, 169, 2-12. Retrieved from https://linkinghub.elsevier.com/retrieve/pii/S1877042815003171

Widodo, A., Rubiyanti, R. N., \& Nandary, T. (2015). FACTORS INFLUENCING GREEN PURCHASING BEHAVIOR (A STUDY OF UNIVERSITY STUDENTS IN BANDUNG). In Proceedings of 2nd International Conference on Global Trends in Academic Research GTAR-2015, Bandung, Indonesia, 2, 775-785. 
Wijaksana, Indra, T., \& Pradana, M. (2018). OPTIMIZATION OF MARKETING INFORMATION SYSTEM FOR CLOTHING PRODUCTION IN BANDUNG CITY, INDONESIA.

Wijayangka, C., Sisilia, K., \& Ruhendi, E. M. (2017). Customer Attitudes Analysis to Purchase Replica of Casio's Watch (Study in Bandung City Citizen). Proceedings of the 3rd International Conference on Transformation in Communications 2017 (IcoTiC 2017). Atlantis Press. 